\title{
A Quasi-Global Mindset: Psychological and Structural Factors That Made Japanese MNCs Succeed in the West and Struggle in China
}

\author{
Katsuhiko Shimizu \\ Graduate School of Business Administration \\ Keio University \\ 4-1-1 Hiyoshi, Kohoku-ku, Yokohama, Japan \\ Tel: 81-045-564-2023Ｅ-mail: katsus@kbs.keio.ac.jp
}

Received: March 19, 2017

Accepted: April 6, 2018

Published: April 10, 2018

doi:10.5296/wjbm.v4i1.12981

URL: https://doi.org/10.5296/wjbm.v4i1.12981

\begin{abstract}
The aim of this study is examining why many Japanese MNCs, which are embedded in Eastern cultures, were successful in the late 1970s and 1980s in Western markets, but have struggled in Eastern emerging markets such as China since the mid-2000s. The success of Japanese MNCs in Western developed countries, whose cultural, institutional, and business environments are very different from the Japanese market, suggests that Japanese managers were developing global mindsets. Thus, their recent struggle in China, which should have more commonalities with Japanese markets than Western markets, is a puzzle and should provide important implications for both researchers and practitioners. Based on the results of exploratory interviews with senior executives of ten large Japanese MNCs, we proposed the idea of a quasi-global mindset, which characterizes Japanese managers' mindsets that are not truly global but are subjectively global. To the extent that managers erroneously believe they have a global mindset and that traditional organizational structures and systems block opportunities to recognize the problem, managers cannot understand the real problems and thus falsely attribute difficulties to the external environment. This study provides important implications to Japanese MNC managers as well as other MNC managers in terms of articulating the importance as well as the difficulties in obtaining true global mindset.
\end{abstract}

Keywords: Global mindset, Japan, China, Cognitive biases 


\section{Introduction}

As global competition continues to intensify, the importance of a global mindset that allows managers to address differences across countries has attracted renewed attention (Ananthram \& Nankervis, 2014; Hitt, Javidan, \& Steers, 2007; Levy, Beechler, Tylor, \& Boyacigiller, 2007). To the extent that managers must understand the uniqueness of each market, adjust their strategy, and utilize knowledge across local subsidiaries in an increasingly competitive environment, their perception of such heterogeneity and effort to coordinate differences and complexities within firms significantly affect their firms' both short-term and long-term performance (Doz \& Wilson, 2012; Gupta \& Govindarajan, 2002). A global mindset is particularly important when multinational corporations (MNCs) from developed countries enter emerging markets and vice versa in terms of large differences in cultural and market characteristics (e.g., Ananthram \& Nankervis, 2014;). However, it is difficult to change a certain mindset developed in a home country (Gupta \& Govindarajan, 2002; Perlmutter, 1969). In fact, the Boston Consulting Group (2013) reports that a large gap is observed between what executives of many MNCs expect to achieve and what they actually achieve in emerging markets.

Partly because of its importance, a global mindset is often described as a pre-requisite of successful global managers (Hitt et al., 2007). However, it is noticeable that a global mindset is not free from contexts, and it should not be understood as an abstract concept (Langinier \& Froehlicher, 2018; Nadkarni, Herrmann, \& Perez, 2011). Given that significant focus has been devoted to the growing importance of emerging markets (Khanna \& Palepu, 2010; Santangelo \& Meyer, 2011), it is important to understand how and why MNC managers are able or unable to develop a global mindset in such contexts.

In this paper, we explore why and how Japanese MNCs, which are embedded in Eastern culture and were successful in the US and other Western developed markets, have not been very successful in China lately (Bartlett \& Ghoshal, 1992; Horn \& Cross, 2009; Iwatani, Orr, \& Salsberg, 2011). We selected China because it represents emerging markets in terms of market size and growth and thus is important for every MNC. The success of Japanese MNCs in Western developed countries suggests that Japanese managers were developing global mindsets and accumulating important knowledge to compete in markets very different from their home market. Thus, their recent struggle in China, which should have more commonalities with Japanese culture than Western cultures (Li, Karakowsky, \& Lam, 2002; Ronen \& Shenkar, 2013), is a puzzle, and studying this issue should provide important implications for both researchers and practitioners.

We explore this issue both inductively and deductively. After reviewing the literature and developing a preliminary model, we interview senior executives of Japanese MNCs regarding their Chinese operation in detail so that we can open the "black box" and "uncover paradoxes and contradictions, both practical and theoretical" (Doz, 2011, p. 583, 586). We further examine the interview results in contrast with the idea of a global mindset and related earlier research findings (e.g., Gupta \& Govindarajan, 2002; O'Grady \& Lane, 1996; Perlmutter, 1969). 
In the following sections, we first explain our research settings regarding Japanese MNCs. After reviewing the literature and developing an initial model based on the global mindset literature, we provide findings from our interviews, which raise more puzzles. By further examining the "paradoxes and contradictions" (Doz, 2011), we refine our initial model and discuss the implications.

\section{Background and Initial Model}

\subsection{Research Setting}

Japanese MNCs have been praised for their successful globalization in the late 1970s and 1980s (Bartlett \& Ghoshal, 1992; Buckley, 2009; Horn \& Cross, 2009; Porter, 1990). Their success was discussed in such books as "Japan as Number One: Lessons for America" by Harvard professor Ezra Vogel (1979) and was often regarded as a threat to firms in the US and other Western developed countries.

However, it has been widely recognized that many Japanese MNCs have been losing their competitiveness and that they have shown signs of struggle beginning in the mid- to late 2000s. Indeed, Japanese MNCs' proportion of the Fortune Global 500's total revenue was a mere $13 \%$ in 2009 , down from $35 \%$ in 1995 . This tendency is particularly significant in Eastern emerging markets (e.g., Iwatani et al., 2011). According to a recent report from the Boston Consulting Group (2013), among MNCs in developed countries, Japanese MNCs have the highest gap between what they want to achieve and what they actually achieve in emerging markets. This downfall is particularly significant in China, despite its proximity to Japan in terms of physical distance and culture. McKinsey consultants (Iwatani et al., 2011) raise an interesting question: Why are General Motors and Volkswagen more successful in China than Honda and Toyota?

It is important to note that Japanese MNCs have not been non-present or unsuccessful in Eastern emerging markets from the beginning (Horn \& Cross, 2009). On the contrary, for example, as Chinese and other Asian markets have been growing, Japanese MNCs have heavily invested in these markets. In particular, approximately $40 \%$ of Japanese foreign direct investment was targeted China during the 1990s (Delios, Beamish, \& Zhao, 2009). Isobe, Makino, and Montgomery (2000) examine Japanese MNCs in China based on a survey in 1996 and found that early movers and technology-committed leaders enjoyed superior performance. Although emerging markets tend to have unique features, including institutional immaturity, government interventions (Khanna \& Palepu, 2010) and political relationship, that sometimes negatively affect business (Horn \& Cross, 2009), many Japanese MNCs that had superior technological knowledge and other capabilities were successful until the mid-2000s. Given that there remain a few firms that continue to be successful, including Yakult and Pigeon, factors in the external environment, such as state regulations and political issues, cannot completely explain the struggle of other firms that had been successful.

In this paper, we explore answers to the following puzzle: Why are many Japanese MNCs that were successful in Western developed markets in the late 1970s and 1980s and initially successful in Eastern emerging markets struggling in emerging markets such as China lately 
(e.g., Delios \& Henisz, 2000; Horn \& Cross, 2009; Isobe et al., 2000)? This exploration should provide an important basis on which to further develop our understanding of a global mindset. This paper also partially addresses the issue raised by Doz (2011, p. 587): "We know less about how multinationals actually operate today, or about their current 'globalization,' than we did about multinationals at the time of the Harvard Multinational Enterprise project in the 1970s."

\subsection{Global Mindset}

Perlmutter (1969) earlier suggested the basic idea of a global mindset or geocentric (world-oriented) view as a desirable attitude of MNC managers in contrast to ethnocentric (home-country oriented) and polycentric (host-country oriented) views. The ethnocentric attitude is characterized by statements such as "We, the home nationals of X company, are superior to, more trustworthy and more reliable than any foreigners in headquarters or subsidiaries" (Perlmutter, 1969, p. 11), whereas polycentric executives are likely to say, "Let the Romans do it their way. We really don't understand what is going on there," and local managers tend to show ethnocentrism focusing narrowly on their own countries (Perlmutter, 1969, p. 13). The researcher also compared the costs and benefits of each attitude and suggested that the short-term benefits of ethnocentrism tend to be high. Although short-term costs, including communication costs for a geocentric attitude, are high, the researcher suggests that long-term benefits through efficient and effective world-wide operation and resulting profit will be higher.

As globalization accelerates and as international competition further intensifies, a global mindset is an increasingly important characteristic for successful managers (Note 1) In the introduction of a volume that featured a "global mindset," Hitt et al. (2007) begin with an example of Limited Brands, which has over 300 partners and 1,000 factories in 40 countries and stresses the importance of addressing excessive levels of ambiguity, diversity, and complexity with global mindset. In their extensive review of the literature on a global mindset, Levy et al. (2007) note that a global mindset is regarded as a cognitive capability composed of two dimensions: cultural perspective and strategic perspective. The former concerns openness and willingness to learn heterogeneous cultures, which the researchers tie to cosmopolitanism, whereas the latter concerns a cognitive complexity to simultaneously consider diversity and integration (c.f., Doz \& Wilson, 2012; Gupta \& Govindarajan, 2002). Reviewing the past literature on global mindset, Chandwani, Agrawal, and Kedia (2016) similarly emphasize the importance of the ability to understand diverse perspectives (differentiation) and the ability to integrate such perspectives.

Although researchers offer similar yet slightly different definitions of a global mindset, this study utilizes that of Gupta and Govindarajan, (2002, p. 117): "one that combines an openness to and awareness of diversity across cultures and markets with a propensity and ability to synthesize across this diversity." In other words, a global mindset plays a key role in learning new knowledge and integrating it effectively with accumulated extant knowledge for MNCs in successfully entering culturally and institutionally different markets (Ananthram \& Nankervis, 2014). Managers of MNCs from developed countries with a global mindset 
should be able to take advantage of differences in terms of cultures, perspectives, and market characteristics in emerging markets and contribute to success both locally and globally (Chandwani et al., 2016).

\subsection{An Initial Model}

Drawing on extant research, we develop an initial model to uncover the mechanisms underlying the struggle of Japanese MNCs in the Chinese market. To do so, we also refer to Murakawa's work (2009) on the failures of Japanese large mobile phone manufacturers in China as a first guide. Japanese mobile phone manufacturers developed cutting edge technologies. In fact, they were the first companies in the world to install color liquid crystal displays, cameras, internet browsers, electronic money services, and television receivers on mobile phones (Marukawa, 2009, p. 414). However, customer needs and institutional norms in China are very different from those in Japan. Many local competitors developed a large variety of new phones with affordable prices by using standardized parts with less advanced technology. Marukawa (2009, p. 429) concluded:

They [Japanese manufactures] were required either to adopt a more decentralized approach, in which their Chinese subsidiaries managed innovation independently from the headquarters in Japan, or to allocate more resources for overseas market development within a centralized organization.

The finding of Marukawa (2009) is not inconsistent with what Porter's (1990) four-diamond framework explains regarding why many Japanese MNCs succeeded in the late 1970s and 1980s. Japanese MNCs took advantage of their strengths developed in the home market to enter the US and other Western developed markets in the late 1970s and 1980s. Accordingly, in entering emerging markets, it is rational for these firms to use their advantages in high-end products and pursue higher growth than that of Japanese market, as visualized in Figure 1. As long as the core market was high end and as long as no local competitors were able to attain their level, Japanese MNCs were successful in Eastern emerging markets (e.g., Delios \& Henisz, 2000; Isobe et al., 2000).

However, this apparently rational and successful strategy had pitfalls, as explained in Figure 2. To the extent that Japanese MNCs stuck to high quality products based on advanced technology and focused on higher end customers, lower end customers, who rapidly increased and became the majority in emerging markets, were captured by local rivals. Taking advantage of the sheer volume of lower end customers, local rivals generated sufficient cash to imitate and absorb advanced technologies from Japanese (and Western) MNCs (Luo, Sum, \& Wang, 2011). Such emerging economy copycats (EECs) further developed innovative products/services, threatening Japanese MNCs. Thus, although many Japanese MNCs continue to strive to maintain technological and quality advantages over local rivals, the gap appears to be increasingly narrowing. Emerging markets are attractive, but they are increasingly competitive for MNCs from developed countries (Delios \& Henisz, 2000; Khanna \& Palepu, 2010).

Although such theoretical models are understandable, new questions can be raised. Many 


\section{Macrothink}

World Journal of Business and Management

ISSN 2377-4622

2018, Vol. 4, No. 1

Japanese MNCs have long experience in Chinese markets and thus have enough knowledge of local market characteristics, culture (including the importance of Guanxi) and competitors (Delios et al., 2009). It should not be extremely difficult to understand and respond to the strategy of local competitors (Luo et al., 2011). Horn and Cross (2009, p. 297) state that "[g]iven their strong market orientation and cultural heritage, Japanese firms are well placed to exploit the expanding and increasingly accessible mass consumer market in China." Although there are differences in customer preferences, it is well known that Chinese customers love Japanese products, which is characterized by "bakugai (Note 2)" or explosive buying by a large number of Chinese tourists in Japan. Additionally, in the process of succeeding in the US and other Western developed markets, managers in Japanese MNCs should have been developing a global mindset, which would enable them to be successful in emerging markets such as China (Bartlett \& Ghoshal, 1992; Buckley, 2009). Moreover, understanding the cultural and market characteristics of Eastern emerging markets should be easier for Japanese managers, who share more similar Eastern cultural backgrounds than Western cultures and characteristics (Ronen \& Shenkar, 2013). Although managers of Japanese MNCs were open to and aware of the differences between Japanese culture and those of US or other Western countries, they do not appear to have sufficiently familiarized themselves with Eastern emerging markets. As such, many Japanese MNCs made similar strategic mistakes to the mobile phone manufactures in China (Marukawa, 2009). Why?

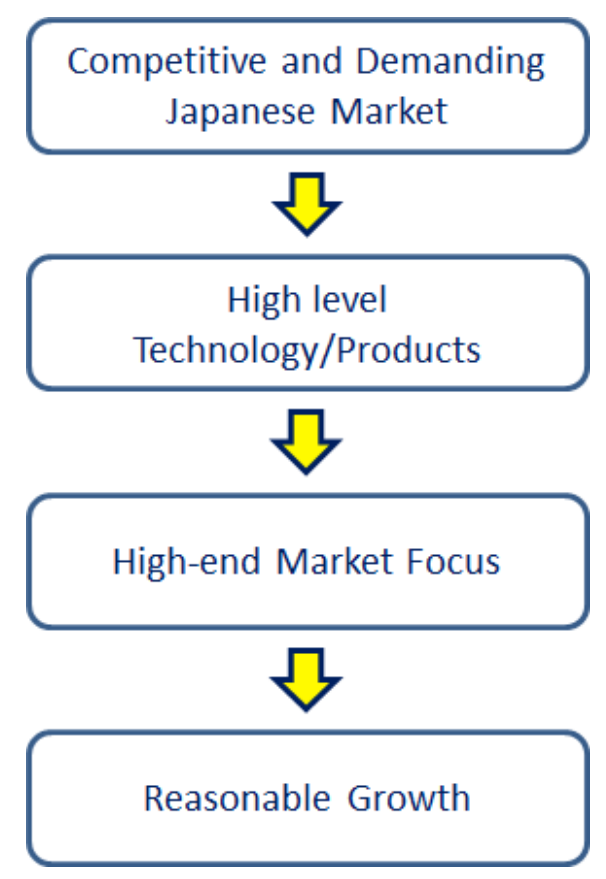

Figure 1. Typical Japanese MNC strategy in emerging markets 


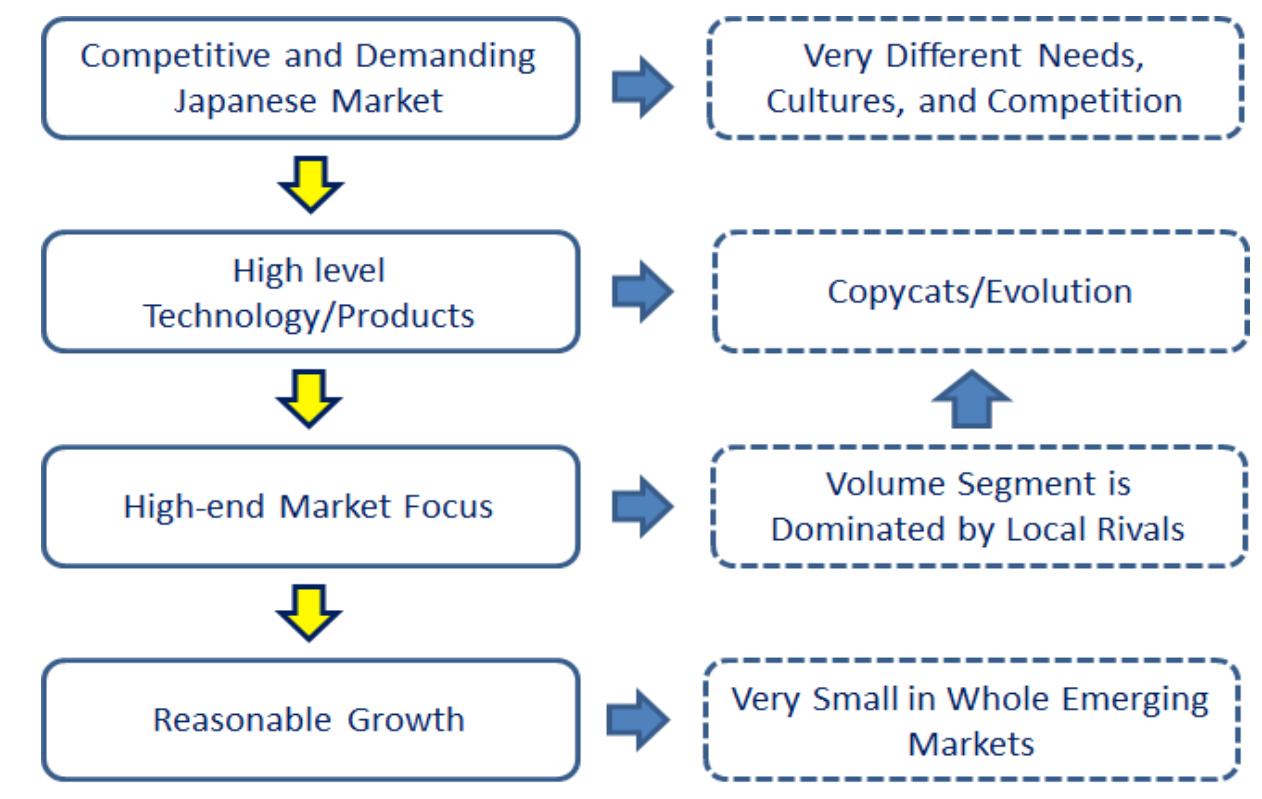

Figure 2. Mechanisms of Japanese MNCs' struggle in emerging markets

\section{Exploratory Interviews and Model Refinement}

\subsection{Approach}

To further explore the puzzles in addition to the issues raised by other researchers (Cheng, Henisz, Roth, \& Swaminathan, 2009; Doz, 2011), we conducted semi-structured exploratory case interviews with senior executives of major Japanese MNCs in 2013 and 2015. The case study is "a research strategy which focuses on understanding the dynamics present within single settings" (Eisenhardt, 1989, p. 534) and is appropriate to obtain insights to help our understanding in underdeveloped areas (Eisenhardt, 1989).

We initially approached 18 firms. In this paper, we present our preliminary findings and analyses of the interviews of ten MNCs in which we were able to interview senior executives who clearly indicated that China is the most important market outside Japan (for some, the US or Europe has remained as important as China). The profiles of the ten MNCs are shown in Table 1. Although the sizes of the sample companies vary, all the interviewees are senior executives of leading public firms in each industry in Japan. In making an appointment with high-ranking executives, we used the business ties of a large accounting firm. Thus, this research is based on convenience sampling; however, we believe that this approach is inevitable as a preliminary step to open a black box (Doz, 2011). Generally, three interviewers met an executive and his subordinates (all the executives were male), and the interviews lasted 90 to 120 minutes. After each interview, a detailed memo was crafted, shared and analyzed by the members. Each memo was also sent to each executive to ensure the accuracy of the interview contents and interpretation.

Initially, we created questions that cover various issues, including current status (e.g., performance, degree of progress, and number of expatriates), marketing, logistics, human 
resource management, subsidiary control, role of the headquarters, and positioning of the Chinese operations within the entire international strategy. Through the iterative process of verifying and comparing the emerging constructs (Strauss \& Corbin, 1998), we eventually found five key questions and responses that provided clues for understanding the struggle of Japanese MNCs. This gradual and iterative process provided the means for a rigorous analysis of a large quantity of qualitative data. The findings were also constantly compared with the literature to clarify the new contributions and to integrate and be integrated with past research findings (Eisenhardt, 1989; Strauss \& Corbin, 1998). The key questions and typical responses are summarized in Table 2.

\subsection{Preliminary Findings}

Although all the sample companies are public, they officially report regional performance in a crude manner by using broad labels such as "North America", "Europe" and "Asia/Oceania." Thus, while we could not obtain comparable objective performance data on their Chinese operations, various sources that we explored, including business journals and reports from analysts, suggested that only one sample company (Company C) was clearly successful. The others were generally behind competitors and markets in terms of sales growth and/or were not very profitable. Although some firms reported double-digit sales growth in overseas sales, Chinese markets grew more. Surprisingly, only three of the ten firms evaluated their operation as "unsatisfactory." Others commented that their progress was either satisfactory or moderately satisfactory given the uncertainty associated with the Chinese market. Managers at both company B and company D were proud of the higher growth in their international operation than that in Japan. A typical comment could be taken from the interview with Company F.

We have some problems due to unfamiliarity with and uncertainties in the Chinese market. However, we are making progress through trial and error. We are happy with where we are now. We expect double-digit growth in China the next few years.

Another interesting but not very surprising observation was that all the companies clearly stated that they would not directly compete with local competitors, which typically focused on the bottom or middle of the market pyramid with low-cost products (c.f., Luo et al., 2011). Consistent with our initial model (Figure 1), Japanese MNCs wanted to take advantage of their advanced technology and high-quality products/services and to target high-end customers. The interviewees were unanimously proud of the high quality of their products and services. They also understood that local competitors were catching up and that the space at the top of the pyramid is getting smaller, while they showed some annoyance toward aggressive imitation moves, some of which did not seem to them to be completely legal, by local competitors.

Third, in emerging markets, MNCs were reported to rely heavily on expatriates for subsidiary management owing to the scarcity of management talent in local markets (Harzing, 2001). Japanese MNCs historically used more expatriates than US or European MNCs (Belderbos \& Heijltjes, 2005; Harzing, 2001), and they tended to rotate these expatriates every three to four years between home and abroad. Although such rotation has merits in terms of developing 
individual careers and infusing new ideas into local operations, certain local employees are not committed to the policy of top management because they know that the current top management will be gone soon and that a very different policy may replace the current one. Company $\mathrm{C}$ alone clearly stated that it moves high profile executives and that they should remain for at least ten years. In relation, we found that the cycle of rotation of top management in Chinese subsidiaries was shorter than that in developed countries, although the Chinese market had higher priority. Interestingly, senior executives understood that long tenure was more effective in understanding the institutional mechanisms of the Chinese market and developing strong rapport with local employees as well as local partners. Executives of both Company B and Company G made similar comments:

Typically, top managers change every three years in our company in China. The length is about four to five years in the US and other developed countries. The difference comes from the difference in social infrastructure and uncertainty. Some managers are also concerned about education for their children.

The fourth point also concerned human resource management. We asked each of the executives their major concerns for the Chinese subsidiary. Virtually, all executives agreed that the major concern was the localization of management (c.f., The Boston Consulting Group, 2013; Harzing, 2001). More specifically, Japanese MNCs were struggling with hiring, training, and retaining skilled workers as well as local management talent. The interviewees often compared them with MNCs from the US and Europe and argued that MNCs from those countries tend to hire local talent with high monetary incentives. However, MNCs from Japan could not do so, partly because paying competitive salaries and bonuses will destroy the balance within the entire organization, partly because the salary structure was dominated by seniority and partly because "the Japanese system worked before." It is common that Japanese MNCs hire local young employees and train them and US or European MNCs then poach them. Typical comments are as follows:

There are many people in China. However, if you look for people who can speak either English or Japanese and have managerial talents, they are very rare. Accordingly, we tend to compete with Western rivals all the time. (Company D)

We cannot compete with US MNCs in terms of pay. Thus, we have to impose a unique corporate culture on local employees and share the same values so they want to stay with us.

(Company E)

If we hire people with high salary and a bonus, they will leave if others propose a higher salary and bonus. It is not very productive. Thus, we do not compete with money. At this point, local managers at a high level of local subsidiaries were all hired when they were young and stayed with us because they like us. (Company G)

Finally, we received consistent feedback in terms of the roles of Japanese headquarters. Japanese MNCs typically had a division and an executive in charge of overseas operation. The executive was generally located in Japan, whereas Company $\mathrm{C}$ actually sent its executive to a regional headquarters. In many cases, it was the headquarters located in Japan that made 
key decisions such as resource allocation, coordination, and manager assignment/rotation. Although the centralized decision-making process has merits in pursuing overall total optimization, the interviewees also recognized weaknesses such as inflexibility and limited delegation by the micro-management, which results in slow-decision making.

It is common that even just a 100 yen $(8 \mathrm{CNY})$ raise in employee salary needs to be authorized by headquarters. If local managers do not have authority, there is no reason for local employees to respect them. Although US MNCs tend to give local managers a clear performance goal and a large amount of autonomy, local managers of Japanese MNCs tend to be a mere coordinator. Headquarters do not understand the unique local practices and often demand "rational" explanation. (Company F)

Although the international division of Japanese headquarters is in charge of global business, it is the least globalized division in the entire organization. Thus, we send qualified local staff to headquarters for a few months. It is not only to motivate and allow them to learn the Japanese management style but also to stimulate people at the headquarters. (Company I)

In fact, Nippon Keizai Shimbun on New Year's Day (January $1^{\text {st }}$, 2013) reported a famous acronym that Japanese managers in subsidiaries in Asia use against the headquarters: OKY (Omae Kokonikite Yattemiro, You come here and do by yourself). The article notes that such an acronym reflects the frustration of many Japanese local managers.

Although the interview comments logically explained why the focal companies struggled in China to a large extent (Note 3), our puzzles were not completely solved. In fact, we found new puzzles. Why did many firms say that they are happy with the mediocre growth rate in the Chinese market? If they understood the intense competition with local firms, why did they not respond more effectively? If the frustration of local managers was recognized and shared, why didn't Japanese firms try to change the current control systems? It was our impression that many senior managers understood their problems. Yet, rather than seriously trying to address these problems, they attributed them to "uncontrollable" external factors, such as unique environmental factors and political issues. Moreover, we wondered what happened to the global mindset.

Table 1. Profile of interview companies

\begin{tabular}{|l|l|l|c|c|c|}
\hline & Industry & Interviewee(s) title & $\begin{array}{c}\text { Sales (2013, } \\
\text { billion yen) }\end{array}$ & $\begin{array}{c}\text { Overseas sales } \\
\text { proportion (\%) }\end{array}$ & $\begin{array}{c}\text { Response to } \\
\text { performance in China }\end{array}$ \\
\hline A & Retail & $\bullet$ Division director & 479.0 & $\mathrm{n} / \mathrm{a}$ & unsatisfactory \\
\hline B & Food & $\begin{array}{l}\text { - CFO } \\
-\end{array}$ & 446.0 & 5 & sanager \\
\hline C & $\begin{array}{l}\text { Consumer } \\
\text { products }\end{array}$ & $\begin{array}{l}\text { Department } \\
\text { director }\end{array}$ & 428.4 & 47 & satisfactory \\
\hline
\end{tabular}




\begin{tabular}{|c|c|c|c|c|c|}
\hline D & $\begin{array}{l}\text { Consumer } \\
\text { products }\end{array}$ & $\begin{array}{l}\text { Executive general } \\
\text { manager } \\
\text { Director }\end{array}$ & 352.0 & 19 & very successful \\
\hline $\mathrm{E}$ & Electronic & $\begin{array}{l}\text { - General manager } \\
\text { - Manager }\end{array}$ & 1,903 & 53 & $\begin{array}{l}\text { moderately } \\
\text { satisfactory }\end{array}$ \\
\hline $\mathrm{F}$ & Electronic & - General manager & 150.1 & 70 & satisfactory \\
\hline G & Electronic & $\begin{array}{c}\text { Senior vice } \\
\text { president }\end{array}$ & 6,100 & 55 & satisfactory \\
\hline $\mathrm{H}$ & $\begin{array}{l}\text { Information } \\
\text { technology }\end{array}$ & $\begin{array}{l}\text { Senior vice } \\
\text { president } \\
\text { Vice president }\end{array}$ & 1,033 & 10 & unsatisfactory \\
\hline $\mathrm{I}$ & $\begin{array}{l}\text { Automobile } \\
\text { parts } \\
\text { manufacturing }\end{array}$ & $\begin{array}{c}\text { Senior vice } \\
\text { president }\end{array}$ & 750 & 45 & satisfactory \\
\hline $\mathbf{J}$ & Plant building & - General manager & 197.3 & 15 & $\begin{array}{c}\text { moderately } \\
\text { unsatisfactory }\end{array}$ \\
\hline
\end{tabular}

Table 2. Summary of responses to key questions

\begin{tabular}{|l|l|}
\hline Questions & Responses \\
\hline $\begin{array}{l}\text { Q1. How satisfied are you } \\
\text { regarding the progress in } \\
\text { the Chinese market? }\end{array}$ & $\begin{array}{l}\text { All the respondents admit challenges associated with emerging markets } \\
\text { due to different customer needs, high competition, and uncertainties. } \\
\text { However, the majority of respondents (seven of ten) state } \\
\text { "satisfactory," although information from various sources suggest } \\
\text { otherwise. }\end{array}$ \\
\hline $\begin{array}{l}\text { Q2. Who are the target } \\
\text { customer segments? }\end{array}$ & $\begin{array}{l}\text { All the respondents agree that it is the high-end segment that they are } \\
\text { targeting and that they will not compete with local rivals with price. }\end{array}$ \\
\hline $\begin{array}{l}\text { Q3. How are Japanese } \\
\text { expatriates (management } \\
\text { level) treated? }\end{array}$ & $\begin{array}{l}\text { Most of the respondents suggest that it is approximately 3 4 years } \\
\text { (typically 3 years), which can be shorter than that for the US or other } \\
\text { developed countries. }\end{array}$ \\
\hline $\begin{array}{l}\text { Q4. What is your main } \\
\text { concern in operating and } \\
\text { expanding in China? }\end{array}$ & $\begin{array}{l}\text { Human resource management is the most frequently cited issue by } \\
\text { respondents. Respondents are seriously concerned about hiring, } \\
\text { training, and retaining skilled workers and local management talents. }\end{array}$ \\
\hline $\begin{array}{l}\text { Q5. What is the most } \\
\text { important role of } \\
\text { headquarters? }\end{array}$ & $\begin{array}{l}\text { Although respondents acknowledged the importance of coordination } \\
\text { and resource allocation by headquarters, some suggest that staff at the } \\
\text { headquarters do not know the local business and that headquarters can } \\
\text { be the least globalized division in the company. }\end{array}$ \\
\hline
\end{tabular}




\subsection{Psychological Biases and Quasi-Global Mindset Models}

To approach the new puzzles, we returned to a basic idea: a global mindset. A global "mindset" is the cognitive map of managers (Chandwani et al., 2018; Walsh, 1995). It is not surprising that managers who should have a global mindset are more or less biased (Redding, 2007). In fact, Gupta and Govindarajan (2002, pp. 116-117) note that mindsets in general are "a product of our histories" and that "we either reject new information (that is not consistent with the current mindset) or change our mindset." Redding (2007, pp. 65-66) also suggests that it is possible that "the supposed global mindset achieved so far is no more than a Western, rational, professional, individualist, aggressive version of 'organization man' gone abroad." In other words, even successful MNC managers who are supposed to have global mindsets are vulnerable to various psychological biases, such as overconfidence and inertia, that prevent them from correctly observing and understanding their current status (Redding, 2007; Shimizu \& Hitt, 2004).

Psychological biases in the context of international business are well known, for example, as a source of psychic distance paradox (Evans \& Mavondo, 2002; O'Grady \& Lane, 199), and this line of research can provide us with useful insights for untangling our puzzles. Psychic distance is defined to concern "factors preventing or disturbing a firm's learning about and understanding of a foreign environment" (Nordstrom \& Vahlne, 1992, p. 3). Thus, it is generally assumed that MNC managers tend to choose to enter a host country that has low psychic distance from its home country (Nordstrom \& Vahlne, 1992). However, observing that many Canadian retailers are not very successful in the U.S., whose psychic distance from Canada should be low, O'Grady and Lane (1996) posit the psychic distance paradox concept. "The psychic distance paradox is that operations in physically close countries are not necessarily easy to manage because assumptions of similarity can prevent executives from learning about critical differences" (O'Grady \& Lane, 1996, p. 309). Stressing the importance of perceived, not objective, psychic distance, they argue that mental models based on the assumption of similarity prevent the top managers of Canadian retailers from correctly realizing fundamental errors and interpreting market research. Finally, they suggest four sources of such biases or "myths": similarity, proximity, success, and (market) size and certainty.

Along this line, Selmer and Lauring (2013) find an "open-minded/ethnocentric paradox." Arguably, Danish managers are the most open minded and global. However, such confidence has stopped Danish managers from observing their own weaknesses and made them autocratic and less sensitive to other cultures and nationalities. More recently, Langinier and Froehlicher (2018) show that the prevalent notion of the importance of expatriates' relationship with locals is not universally true and that the importance is context dependent.

When entering the US market, Japanese MNCs were not as advanced or sophisticated as their US competitors. Moreover, cultural and market differences are significant. Consequently, many Japanese managers needed to be open and willing to learn from the US market and US competitors. It is well known that the total quality management developed by Edward Deming in the US, which many US firms ignored, was adopted by many Japanese firms. 
Thus, the mindset of Japanese managers in the US evolved from ethnocentric to global, both subjectively and objectively (Perlmutter, 1969). Combined with the technological capabilities and commitment to quality developed in the domestic market, Japanese MNCs were able to learn and outperform US competitors in the late 1970s and 1980s (Bartlett \& Ghoshal, 1992; Buckley, 2009).

After the experience of learning different cultures and institutional practices in the US and other Western developed countries, the mindset of Japanese MNC managers became more global (Bartlett \& Ghoshal, 1992). Thus, the managers could be successful in China by being continuously open to and learning from the Chinese culture and customer needs (Ananthram \& Nankervis, 2014; Horn \& Cross, 2009). Moreover, the cultural differences between Japan and the US are much larger than those between Japan and China, both of which belong to the same Confucian category (Ronen \& Shenkar, 2013). However, to the extent that Japan was perceived to be economically superior, Japanese MNCs were more technologically advanced, and Chinese markets and competitors were regarded as less sophisticated, Japanese managers appeared to become unconsciously more ethnocentric and less open to and less willing to learn from the Chinese market and local competitors.

Likely, some managers recognized these problems. However, because of the frequent rotation of country managers, the limited number of local executives, and the biases and micro-management tendency of headquarters, these problems were not clearly understood or shared within Japanese MNCs. Thus, whereas many managers of Japanese MNCs, particularly those in the headquarters, may have thought that they were internationally experienced and thus that their mindset was global, such (over)confidence may have made their mindset less geocentric and more ethnocentric.

Interestingly, research suggests that MNCs with ethnocentric attitudes or a domestic mindset perform well at an early stage of internationalization (Nadkarni et al., 2011). The findings of Delios and Henisz (2000) and Isobe et al. (2000) also support this argument. For Japanese MNCs, "Japan quality" and "Japan brand" were a very strong weapon. This early success further strengthened the belief of Japanese MNC managers regarding their global mindset and reinforced the misunderstanding (Shimizu \& Hitt, 2004). However, as we observe, the success did not last very long (The Boston Consulting Group, 2013; Iwatani et al., 2011).

Probably, the fundamental problem is that Japanese MNC managers did not understand the true cause of their struggle, similar to Canadian managers described by O'Grady and Lane (1997) and Danish managers described by Selmer and Lauring (2013). The managers believed that they listened to local customers and understood local cultures. In other words, although they believed that they had a global mindset, the mindset was subjectively and superficially global, which is what we call a quasi-global mindset. The managers likely unconsciously ignored or denied important information and opportunities (Gupta \& Govindarajan, 2002; Shimizu \& Hitt, 2004). Moreover, the quasi-mindset was exacerbated by structural problems (frequent rotation, limited number of local executives, and micro-management by headquarters), and a bad cycle continued.

Because mindset has a self-reinforcing nature, managers will not recognize that they are 
biased. Instead, managers attribute their poor performance to external factors, such as uncertain local institutional environments (Santangelo \& Meyer, 2011).

We believe that these factors are the reason that we heard the word "uncertainty" repeatedly during the interviews. It appears that because the managers could not understand why they were not successful, they attributed the problems to external uncertainties in various areas, including legal systems and regulations, customer needs, and competition. It is true that higher uncertainties exist in emerging markets than in Japan or the US (Ng et al.; 2009; Santangelo \& Meyer, 2011). Regulations are often unclear and unstable in emerging markets (Khanna \& Palepu, 2010; Santangelo \& Meyer, 2011). However, uncertainties involve not only risks but also opportunities (Evans \& Mavondo, 2002). To the extent that Japanese MNC managers believe that such uncertainties are out of their control, they would be satisfied with mediocre performance. Moreover, the managers under pressure of headquarters became defensive and were not able to take advantage of the emerging opportunities (Chattopadhyay, Glick, \& Huber, 2001).

We argue that the perception of high external uncertainty resulted in various strategic missteps, particularly when MNCs need to grow, which requires large investments (Marukawa, 2009). The perception of high uncertainty prevented many Japanese MNCs from investing at a threshold level in terms of production, distribution, and human resources (Iwatani et al., 2011). The perception of high uncertainty also leads to less delegation and risk taking, which resulted in not only slow decision making but also slow understanding of local institutional norms and practices (Fitzgerald \& Rui, 2016). The short rotation cycle of expatriate top management combined with a limited number of local executives further limited their learning opportunities and exacerbated the perception of uncertainty. Because Japanese MNCs limit investment in order to avoid risks associated with uncertainty, they learn minimally, which results in the continuous prevalence of uncertainty. It appears that Japanese MNCs were trapped in this bad cycle and failed to compete effectively with EECs in emerging markets (Luo et al., 2011).

To verify our analysis, we asked three Chinese professionals how they perceive Japanese MNCs in China. Although all of them are familiar with Japanese MNCs, such as Toyota and Sony, their reactions to Japanese MNCs were generally lukewarm. One person said, "Several years before Japanese firms enjoyed their golden age in China, but it ended. Although the quality of Japanese firms may still be better, local competitors provide good quality products at a lower price." Another person said, "I have an impression that Japanese firms are passive, compared to local firms or even to Korean firms." Their observations and impressions coincide with our analysis. It is true that Japanese MNCs and their products still command a high premium "image," but the image is not strong enough to penetrate the growing middle or volume market in China. Moreover, the passiveness suggests that many Japanese MNCs have been or are losing confidence. It is not surprising because our interviewees actually felt that they are at the mercy of uncertainties and uncontrollable factors in China (c.f., Chattopadhyay et al., 2001).

Thus, we argue that the problems that Japanese MNCs have in Chinese markets are not as 


\section{Macrothink}

World Journal of Business and Management

ISSN 2377-4622

2018, Vol. 4, No. 1

much strategic mistakes due to insufficient knowledge of local needs and environments as unconscious mindset problems resulting from a rigid quasi-global mindset historically developed through success in the US and other Western developed markets exacerbated by structural problems such as traditional human resource systems and micro-management by headquarters. Based on this argument, we provide three propositions that may be applicable to both Japanese and non-Japanese MNCs from developed countries in Eastern emerging markets:

Proposition 1: The degree of a quasi-global mindset (i.e., the degree of a gap between the subjective perception and objective reality) (Note 4) of MNC managers is negatively associated with performance in emerging markets.

Proposition 2: The degree of a quasi-global mindset among MNC managers is positively associated with the degree of past success in culturally different markets, the frequency of country manager rotation, the scarcity of local executives, and the degree of the lack of delegation.

Proposition 3: The degree of a quasi-global mindset among MNC managers is positively associated with the degree of perceived uncertainty in emerging markets.

The refined models that we developed by using our interview findings and by incorporating psychological biases (i.e., quasi-global mindset) are shown in Figures 3 and 4.

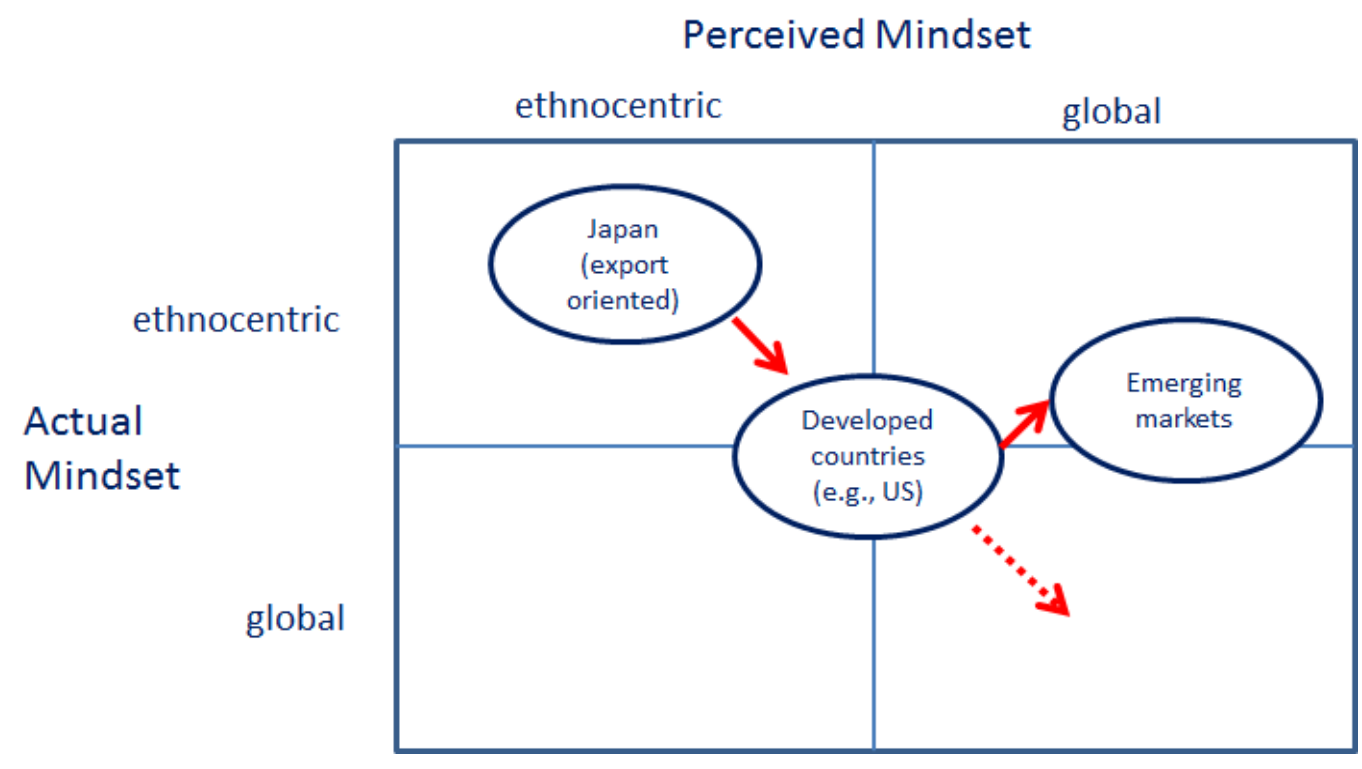

Figure 3. Evolution of Mindset of Japanese MNC managers (Perils of Quasi Global Mindset) 


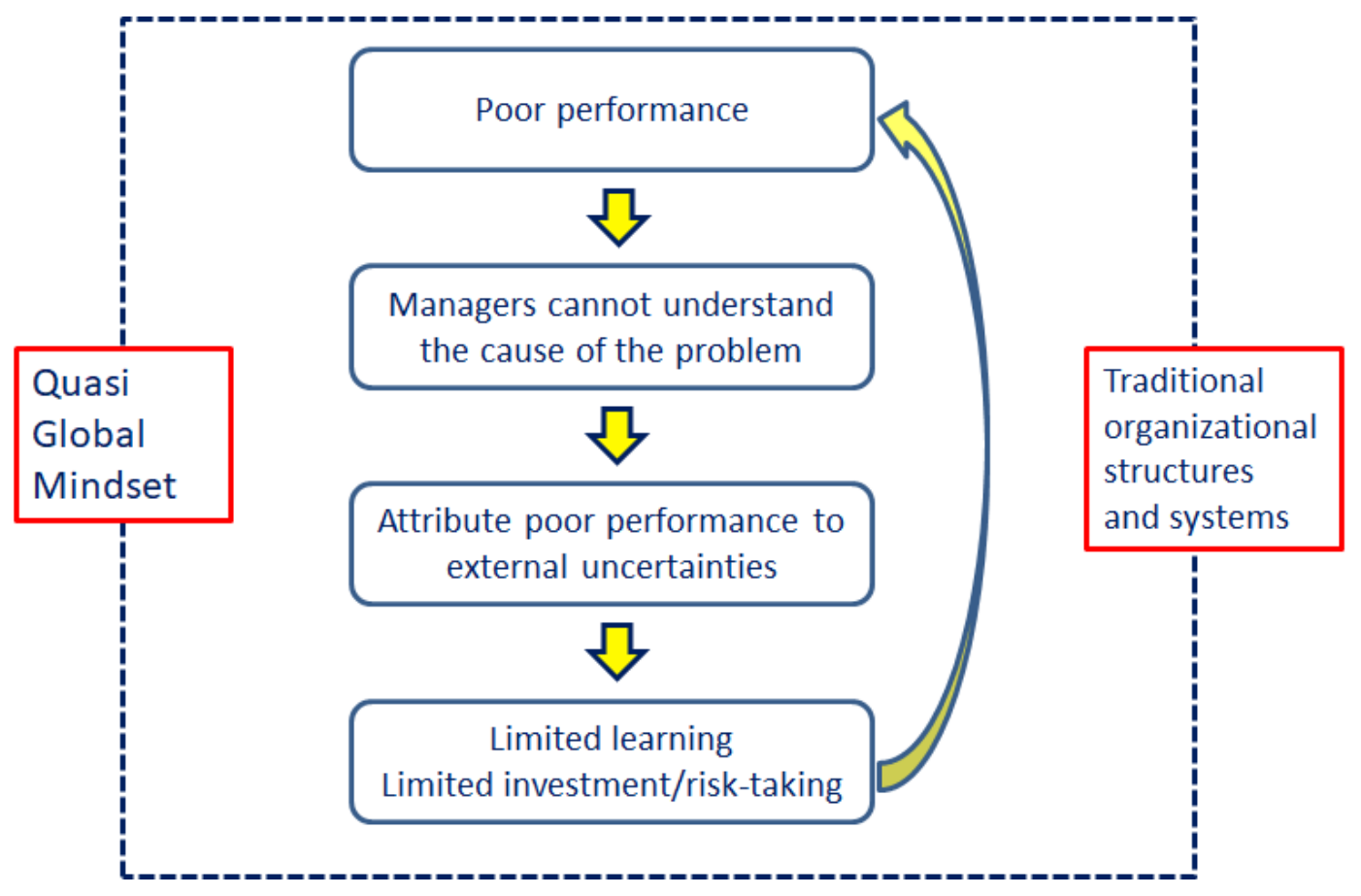

Figure 4. Refined Mechanisms of Japanese MNCs' struggle in emerging markets

\section{Conclusion and Managerial Relevance}

\subsection{Conclusion}

In this study, we attempt to provide a preliminary step to answer the question in terms of how MNCs from developed countries compete in emerging markets (Cheng et al., 2009) from the perspective of a global mindset (Ananthram \& Nankervis, 2014; Hitt et al., 2007; Levy et al., 2007). In doing so, we examined a puzzle: Japanese MNCs that should have not only world-class products and technologies but also a global mindset have struggled in culturally similar emerging markets, such as China. After iteratively referring to the literature and exploratory interview results with Japanese senior managers, we proposed a concept of $a$ quasi-global mindset, a state of mind that occurs when managers believe they are open to and willing to learn from local cultures but are in fact more self-centered and narrow minded (c.f., Levy et al., 2007; Gupta \& Govindarajan, 2002; Redding, 2007). Because research on global mindset is often prescriptive, we contribute to the literature by exploring how a global mindset works and does not work in a specific context, i.e., in Eastern emerging markets. We believe that the idea of a quasi-global mindset extends our understanding of why many Japanese MNCs have been very successful in Western markets and at an early stage of Eastern emerging markets yet have been struggling to expand further in emerging markets.

There are a number of limitations in this study. Our research is exploratory and the sample is limited in terms of number and nationality. Although we specifically pay attention to potential noises in interviewing and interpreting the results, the possibility that other factors such as political relationship between Japan and China confounded the results cannot be completely 
eliminated with our approach. Additionally, further examination by operationalizing global mindset construct is needed. Yet, we believe that we have partially opened the "black box" and "uncover[ed] paradoxes and contradictions, both practical and theoretical" (Doz, 2011, pp. 583-586). This research also provides some implications in terms of explaining why research on cultural and institutional differences still provide mixed results (e.g., Hitt. Li, \& $\mathrm{Xu}, 2016$ ). Similar to the psychic distance paradox (O'Grady \& Lane, 1997), more insights may be obtained by incorporating perceptions of managers in such lines of research.

\subsection{Managerial Relevance}

This research also has important practical implications. Three McKinsey consultants discuss the problems of the unsuccessful globalization of Japanese MNCs (Iwatani et al., 2011) and recommend five prescriptions:

- Making the strong case of globalization for employees in terms of global goals, aspirations, and value propositions.

- Adopting English as the company language

- Designing an aggressive talent-management strategy that can embrace diversity and global rotation

- Building a global marketing function

- Attaining more from strategic corporate development by utilizing integration and the resulting synergies across international subsidiaries

We believe that their assessment is valid and that the recommendations are useful. However, our models show a more fundamental problem of Japanese MNCs: the quasi-global mindset resulting from a failure to unlearn early success. Such a quasi-global mindset is further exacerbated by structural problems, including frequent rotation, a lack of local executives and micro-management by headquarters, which generally helped Japanese MNCs succeed in US and European markets in 70s and 80s (Porter, 1990; Vogel, 1979). These established structures hindered managers from recognizing that their view was self-centered; thus, they failed to capture reality in emerging markets (Gupta \& Govindarajan, 2002; Shimizu \& Hitt, 2004). Consequently, many managers of unsuccessful MNCs are attributing their struggles to external uncertainties in emerging markets, which could further increase the control by headquarters, and they are satisfied with mediocre achievement (c.f., Chattopadhyay et al., 2001). Unless Japanese MNC managers, particularly those in headquarters, recognize that their mindset is quasi-global, it will be very difficult to make meaningful progress. Managers in MNCs in other developed countries may have similar experience. It is important to note that frequent rotation and micro-management by headquarters may not be detrimental by themselves. They have merits. However, they work negatively in the context of Chinese markets with managers with a quasi-global mindset (e.g., Langinier \& Froehlicher, 2018).

To this end, it is worth mentioning that Mr. Yoshida, Chairman and CEO of YKK, the world largest zipper manufacturer headquartered in Japan, clearly stated on March 2, 2017, that YKK is going to emphasize volume market and compete with Chinese competitors head to 
head. It seems that some Japanese MNCs eventually found the real problem.

Overall, it is our understanding that it is not a lack of knowledge or capability that contributes to the demise of Japanese MNCs in China. It is a lack of understanding of what truly made Japanese MNCs succeed in the 1970s and 1980s in the context of Western markets. Although we used a sample of Japanese MNCs, many other successful MNC managers can easily be trapped with a quasi-global mindset. Future research could further examine such issues quantitatively and extend our understanding in terms of the importance as well as the difficulty of truly acquiring a global mindset to successfully acquire, integrate, and utilize knowledge in diverse markets.

\section{References}

Ananthram, S., \& Nankervis, A. R. (2014). Outcomes and benefits of a managerial global mind-set: An exploratory study with senior executives in North America and India. Thunderbird International Business Review, 56, 193-209. https://doi.org/10.1002/tie.21611

Bartlett, C. A., \& Ghoshal, S. (1992). Organizing for worldwide effectiveness: The transnational solution. California Management Review, 31(1), 54-74. https://doi.org/10.2307/41166538

Belderbos, R., \& Heijtjes, M. G. (2005). The determinants of expatriate staffing by Japanese multinationals in Asia: Control, learning and vertical business groups. Journal of International Business Studies, 36, 341-354. https://doi.org/10.1057/palgrave.jibs.8400135

Buckley, P. J. (2009). The rise of the Japanese multinational enterprise: Then and now. Asia Pacific Business Review, 15, 309-321. https://doi.org/10.1080/13602380802667247

Chandwani, R., Agrawal, N. M., \& Kedia, B. L. (2016). Mindfulness: Nurturing global mind-set and leadership. Thunderbird International Business Review, 58, 617-625. https://doi.org/10.1002/tie.21760

Chattopadhyay, P., Glick, W. H., \& Huber, G. P. (2001). Organizational actions in response to threats and opportunities. Academy of Management Journal, 44, 937-955. https://doi.org/10.5465/3069439

Cheng, J. L. C., Henisz, W. J., Roth, K., \& Swaminathan, A. (2009). From the editors: Advancing interdisciplinary research in the field of international business: Prospects, issues and challenges. Journal of International Business Studies, 40, 1070-1074. https://doi.org/10.1057/jibs.2009.41

Delios, A. Beamish, P. W., \& Zhao, X. (2009). The evolution of Japanese investment in China: from toys to textiles to business process outsourcing. Asia Pacific Business Review, 15, 323-345. https://doi.org/10.1080/13602380802667296

Delios, A., \& Henisz, W. J. (2000). Japanese firms' investment strategies in emerging economies. Academy of Management Journal, 43, 305-323. https://doi.org/10.5465/1556397

Doz, Y. (2011). Qualitative research for international business. Journal of International 
Business Studies, 42, 582-590. https://doi.org/10.1057/jibs.2011.18

Doz, Y., \& Wilson, K. (2012). Managing Global Innovation: Frameworks for Integrating Capabilities around the World. MA: Harvard Business Review Press.

Eisenhardt, K. M. (1989). Building theories from case study research. Academy of Management Review, 14, 532-550. https://doi.org/10.5465/amr.1989.4308385

Evans, J., \& Mavondo, F. T. (2002). Psychic distance and organizational performance: An empirical examination of international retailing operation. Journal of International Business Studies, 33, 515-532. https://doi.org/10.1057/palgrave.jibs.8491029

Fitzgerald, R., \& Rui, H. (2016). Whose fall and whose rise? Lessons of Japanese MNCs for Chinese and emerging economy MNCs. Asia Pacific Business Review, 22, 534-566. https://doi.org/10.1080/13602381.2016.1168624

Gupta, A. K., \& Govindarajan, V. (2002). Cultivating a global mindset. Academy of Management Executive, 16(1), 116-126. https://doi.org/10.5465/ame.2002.6640211

Harzing, A. W. (2001). Who's in charge? An empirical study of executive staffing practices in foreign subsidiaries. Human Resource Management, 40, 139-158. https://doi.org/10.1002/hrm.1004

Hitt, M. A., Javidan, M., \& Steers, R. M. (2007). The global mindset: An introduction. In M. Javidan, R. M. Steers, \& M. A. Hitt (Eds.), The Global Mindset: Advances in International Management (No. 19, pp. 1-10). Elsevier.

Hitt, M. A., Li, D., \& Xu, K. (2016). International strategy: From local to global and beyond. Journal of World Business, 51, 58-73. https://doi.org/10.1016/j.jwb.2015.08.016

Horn, S. A., \& Cross, A. R. (2009). Japanese management at a crossroads? The changing role of China in the transformation of corporate Japan. Asia Pacific Business Review, 15, 285-308. https://doi.org/10.1080/13602380802667221

Isobe, T., Makino, S., \& Montgomery, D. B. (2000). Resource commitment, entry timing, and market performance of foreign direct investment in emerging economies: The case of Japanese international joint venture in China. Academy of Management Journal, 43, 468-484. https://doi.org/10.5465/1556405

Iwatani, N., Orr, G., \& Salsberg, B. (2011). Japan's global imperative. McKinsey Quarterly, (June), 1-11.

Khanna, T., \& Palepu, K. G. (2010). Winning in Emerging Markets. Cambridge: MA. Harvard Business Press.

Langinier, H., \& Froehlicher, T. (2018). Context matters: Expatriates' adjustment and contact with host country nationals in Luxembourg. Thunderbird International Business Review, 60, 105-119. https://doi.org/10.1002/tie.21835

Levy, O., Beechler, S., Taylor, S., \& Boyacigiller, N. A. (2007). What we talk about when we 
talk about 'global mindset': Managerial cognition in multinational corporations. Journal of International Business Studies, 38, 231-258. https://doi.org/10.1057/palgrave.jibs.8400265

Li, J., Karakowsky, L., \& Lam, K. 2002. East meets east and east meets west: The case of Sino-Japanese and Sino-West joint ventures in China. Journal of Management Studies, 36, 841-863. https://doi.org/10.1111/1467-6486.00314

Luo, Y., Sun, J., \& Wang, S. L. (2011). Emerging economy copycats: Capability, environment, and strategy. Academy of Management Perspectives, 25(2), 37-56. https://doi.org/10.5465/amp.25.2.37

Marukawa, T. (2009). Why Japanese multinationals failed in the Chinese mobile phone market: A comparative study of new product development in Japan and China. Asia Pacific Business Review, 15, 411-431. https://doi.org/10.1080/13602380802667387

Nadkarni, S., Herrmann, P., \& Perez, P. D. (2011). Domestic mindsets and early international performance: The moderating effect of global industry conditions. Strategic Management Journal, 32, 510-531. https://doi.org/10.1002/smj.888

Ng, D., Westgren, R., \& Sonka, S. (2009). Competitive blind spots in an institutional field. Strategic Management Journal, 30, 349-369. https://doi.org/10.1002/smj.741

Nordstrom, K., \& Vahlne, J. (1992). Is the globe shrinking? Psychic distance and the establishment of Swedish sales subsidiary during the last 100 years. Paper presented at the International Trade and Finance Association's Annual Conference. April 22-25, Laredo, TX.

O'Grady, S., \& Lane, H. (1996). The Psychic Distance Paradox. Journal of International Business Studies, 27, 309-33. https://doi.org/10.1057/palgrave.jibs.8490137

Perlmutter, H. (1969). The tortuous evolution of the multinational corporation. Columbia Journal of World Business, 4(1), 9-18.

Porter, M. E. (1990). The Competitive Advantage of Nations. New York: NY. Free Press.

Redding, G. (2007). The chess master and the 10 simultaneous opponents: But what if the game is porker? Implications for the global mindset. In M. Javidan, R. M. Steers, \& M. A. Hitt (Eds.), The Global Mindset: Advances in International Management (No. 19, pp. 49-73). Elsevier.

Ronen, S., \& Shenkar, O. (2013). Mapping world cultures: Cluster formation, sources and implications. Journal of International Business Studies, 44, 867-897. https://doi.org/10.1057/jibs.2013.42

Santangelo, G., \& Meyer, K. E. (2011). Extending the internationalization process model: Increases and decreases of MNE commitment in emerging economies. Journal of International Business Studies, 42, 894-909. https://doi.org/10.1057/jibs.2011.25

Selmer, J., \& Lauring, J. (2013). Globalizing Denmark. International Studies of Management and Organizations, 43, 9-25. https://doi.org/10.2753/IMO0020-8825430101 


\section{Macrothink}

World Journal of Business and Management

ISSN 2377-4622

2018, Vol. 4, No. 1

Shimizu, K., \& Hitt, M. A. (2004). Strategic flexibility: Organizational preparedness to reverse ineffective strategic decisions. Academy of Management Executive, 18(4), 44-59. https://doi.org/10.1016/j.sbspro.2013.10.528

Strauss, A. L., \& Corbin, J. (1998). Basics of Qualitative Research. Thousand Oaks, CA: Sage.

The Boston Consulting Group. ( 2013). Globalization readiness survey.

Vogel, E. (1979). Japan As Number One: Lessons for America. MA: Harvard University Press.

Walsh, J. P. (1995). Managerial and organizational cognition: Notes from a trip down memory lane. Organization Science, 6, 280-321. https://doi.org/10.1287/orsc.6.3.280

\section{Notes}

Note 1. Researchers discuss level issues in terms of whether a global mindset is an individual-level construct or a firm-level construct (e.g., Ananthram \& Nankervis, 2014; Chandwani et al., 2016; Levy et al., 2007). We mainly focus on individuals (i.e., managers), while we also acknowledge that managers influence and are also influenced by the firm-level mindset, similar to a cognitive map construct (Walsh, 1995). Thus, we also refer to the firm level.

Note 2. "Bakugai" was selected as one of the most memorable buzzwords in 2015 in Japan.

Note 3. Some researchers and consultants also attribute the problems to the Japanese management style such as centralized decision making based on interviews of Japanese executives (e.g., Fitzgerald \& Rui, 2016; Ichii et al., 2012).

Note 4. We understand it critical to consider the operationalization of this construct for future empirical research. At this point, however, there is no empirical study that has operationalized global mindset. Accordingly, we note this as a future issue in the next section.

\section{Copyright Disclaimer}

Copyright for this article is retained by the author(s), with first publication rights granted to the journal.

This is an open-access article distributed under the terms and conditions of the Creative Commons Attribution license (http://creativecommons.org/licenses/by/3.0/). 